DOI https://doi.org/10.36059/978-966-397-160-5/83-105

\title{
UKRAINIAN PRINTED MEDIA OF ROMANIA: A HISTORICAL-POLITICAL AND ETHNOCULTURAL DISCOURSE
}

\section{Yuriy Bidzilya}

\section{INTRODUCTION}

Taking into consideration the historical-political and social conditions, the author of the paper gives complex analysis of the peculiarities of the ethnocultural communication of the Ukrainians of Romania, the establishment and development of the Ukrainian-language press in this country, examines the main problems of the modern functions of the Ukrainian printed mass media and outlines the possible perspectives of their development. The Ukrainian language went through changes in education and mass media in Romania. The situation of the Ukrainian mass media worsened in Romania during the interwar period (especially in the 1930s) due to assimilation processes and turning Ukrainians into Romanians. The government of Romania of the time closed Ukrainian schools, newspapers and cultural establishments. It was forbidden to use Ukrainian in public life. Violating the law could lead to the intervention of the police. The expansion of the Ukrainian information communication segment in Romania began with the introduction of the native-language primary and second education (7 grades) in 1948. It was allowed by the new law of the reformation of the public education passed by the Great National Assembly of Romania. There were 116 Ukrainian-language schools of various degree levels and 4 lyceums (Sighetu Marmației, Tulcea, Suceava and Siret) that prepared teachers for Ukrainian schools in the villages of Romania between 19481960. Such development of the Ukrainian language allowed the publication of the Vilne Slovo ("Free word") biweekly newspaper in Romania in 1949. It was the only means of published Ukrainian mass media for a long time. The ' $40 \mathrm{~s}$ and $50 \mathrm{~s}$ of the $20^{\text {th }}$ century were characterized by the most energetic publication activity of the Ukrainians of Romania. Aside from school textbooks and public-political literature, works of poets and writers were published in the native language. New Ukrainian journals, in particular, Novyi vik ("New era") with its "Literaturnyi dodatok" ("Literary appendix") were published in Romania 
at the time. The latter became a separate literature and arts journal under the title Nash holos ("Our voice"). However, following the sudden death of Gheorghe Gheorghiu-Dej (1965), Nicolae Ceauşescu came to power. His political rule turned out to be devastating for all non-Romanian ethnonational groups and ethnic press of the country. The Ukrainian mass media were repressed by the Communist totalitarian regime and the control of the Securitate secret service in Romania at the time. The situation of the Ukrainian-language mass media somewhat improved after the fall of Ceauşescu's totalitarian regime (1989). The Union of the Ukrainians of Romania was established in Romania at this time (1990). The ethnic organization is publishing 4 printed mass media for the Ukrainians of Romania at the moment: Ukrainskyi visnyk ("Ukranian herlad"), Vilne slovo journals, Dzvonyk ("Little bell") children's journal and Ukrainskyi kurier ("Ukrainian courier") journal (in Romanian). According to the author's mind, the Ukrainian printed mass media of Romania are too weak today, they are published irregularly, have too weak influence on the cultural life of the Ukrainian group in this country. Though, it is a positive point that the Ukrainian media are partly, at least, but supported by the government of Romania thanks to the legislation of the EU. According to the researcher, the future of preserving the Ukrainians as an autochthonous ethnos in this territory and the Ukrainian editions in Romania is only possible with the joint efforts of the two countries: Romania and Ukraine.

\section{Formulation of the problem}

The peculiarity of the situation of the ethnic groups of Romania, their communication with the titular nation and each other are directly connected with the historical background and circumstances of the different periods of the country. The history of the circumstances due to which Ukrainians appeared in Romania is complicated and unique for every region where they live in groups. Similarly to Slovakia, Poland and partly Hungary, the Ukrainians of this country are located on their ethnic territory, prevailingly, in the borderlands close to Ukraine.

The difficulty of the progress of the native-language media and culture of the Ukrainians of Romania, in general, lies in the fact that the politics of this country had been aimed at the assimilation and denationalization of the alien ethnic groups for a long time. According to the researchers' mind, all the circumstances of the social-political life of the Ukrainian community of Romania confirm that "the Ukrainian national minority of Romania could not have preserved its unity in the struggle for its national identity (language, 
spirituality and culture) without its own printed periodicals" ${ }^{1}$. At the same time, scholars point out "the systematic violation of the rights of the national minorities during the entire $20^{\text {th }}$ and the beginning of the $21^{\text {st }}$ centuries of the Romanian government, regardless of the status, model, political orientation "color" of the corresponding structures"2: military administrations of World War I, the Kingdom of Romania of the interwar period, fascist dictatorship of World War II, people's democratic or socialist power of the '40-'60s of the last century, Nicolae Ceaușescu's totalitarian regime (1965-1989), or the social-political transition period of the Romanian society from the socialist to the democratic system $(1990-2006)^{3}$.

The Ukrainians is one of the ethnic groups of Romania that has been living on its territory for centuries and has been undergoing assimilation processes for almost the same duration. There have been no accurate data on the population of the Ukrainians in Romania for a long time. According to the official Romanian census of January 7, 1992, the ethnic composition of the population was as follows: 20324892 Romanians (89.3\%), 1619368 Hungarians (7.1\%), 409731 Roma people (1.8\%), 111301 Germans (0.5\%) and 66483 Ukrainians $(0.3 \%)$. In addition, there are 23 ethnic groups the total of which does not exceed $1 \%$ of the population (224 175 people) $)^{4}$. According to the census of 2002, the Ukrainian community has decreased and constitutes 61.4 thousand people. This makes up $0.3 \%$ of the entire population of Romania and the Ukrainian community is the fourth largest ethnic group 5 .

Analysis of research. In order to get a deeper insight into the peculiarity of the functioning of the contemporary Ukrainian-language mass media of

\footnotetext{
${ }^{1}$ Voloschuk Y. I. (2015) Problematyka periodyky ukrayinskoi natsionalnoi menshyny v Rumunii / Naukovyi chasopys NPU im. M. P. Dragomanova. Ser. 22: Politychni nauky ta metodyka vykladannia suspilnopolitychnykh dystsyplin. [The problem of the periodicals of the Ukrainian national minority of Romania / The scientific periodical of the National Pedagogical Dragomanov University. Ed. 22: Political sciences and the methodology of teaching social sciences]. Kyiv: NPU im M. P. Dragomanova. Ed.: 16. P. 82. [in Ukrainian].

2 Rendiuk T. G. [2010] Ukrayintsi Rumuniyi: natsionalno-kulturne zhyttia ta vzayemovidnosyny z vladoyu [Ukrainians in Romania: national and cultural life and relations with the authorities] Kyiv: Instytut istoriyi Ukrayiny NAN Ukrayiny. P. 7. [in Ukrainian].

3 Rendiuk T. G. [2010] Ukrayintsi Rumuniyi: natsionalno-kulturne zhyttia ta vzayemovidnosyny z vladoyu [Ukrainians in Romania: national and cultural life and relations with the authorities] Kyiv: Instytut istoriyi Ukrayiny NAN Ukrayiny. P. 7-8. [in Ukrainian].

${ }^{4}$ Ukrayina $\mathrm{v}$ suchasnomy heopolitychnomy prostory: teoretychnyi I prykladnyi aspekty: [kol. Monogr.]./za red. F. Rudycha [Ukraine in the modern geopolitical space: theoretical and applied aspects: [col. monograph] / under the edited by F. Rudych. Kyiv: MAUP. 2002. P. 412. [in Ukrainian].

5 Rendiuk T. G. [2010] Ukrayintsi Rumuniyi: natsionalno-kulturne zhyttia ta vzayemovidnosyny z vladoyu [Ukrainians in Romania: national and cultural life and relations with the authorities] Kyiv: Instytut istoriyi Ukrayiny NAN Ukrayiny. P. 142; 329. [in Ukrainian].
} 
Romania and their features, we are about to take a brief retrospective historical analysis of those circumstances that led to the appearance and existence of this press. Passingly, we would like to note that Romania is still among those neighboring countries that have, though, unofficially, territorial claims against Ukraine. This was disputed both in high diplomatic circles and mass media ${ }^{6}$. Places of high concentration of Ukrainians in Romania are Maramureș (more than 36 thousand people), (Southern) Bukovina (more than 10 thousand people), Banat (around 10 thousand people) and Dobruja (more than 3.8 thousand people) counties. Ukrainians comprise the majority in Bistra, Maramureș, Rona de Sus, Timiș and Caraș-Severin municipalities ${ }^{7}$. However, according to the Ukrainian researchers' and diplomats' mind, the number of people speaking Ukrainian exceeds the official number of the Ukrainian population which gives evidence to their political identity as Romanians, though, ethnical identity as Ukrainians. As reported by unofficial sources, the number of the Ukrainians of Romania is between 150 and 220 thousand people, despite all the denationalizing processes. Vladimir Bruter, expert of the International Institute of Humanitarian and Political Studies believes that there are at least 130-140 thousand Ukrainians in the country ${ }^{8}$. The Romanization policy has led to the strong decrease in the number of Ukrainians. As stated in the official census of February 21, 1956, 68.3 thousand Ukrainians lived in Romania in the following counties of the time: 28900 people in Suceava (Rădăuți, Câmpulung Moldovenesc, Dorohoi, Gura Humorului and Vatra Dornei cities) and 25200 people in Maramureș (Vișeu and Sighetu regions) (data taken from the Ukrainian Wikipedia). At the legislative level, the development of the Ukrainian minority of Romania and the information

${ }^{6}$ Appatov S. (1998) Ukrainsko-rumunski vidnosyny: istoriya ta suchasnist. Ukrainskyi istorychnyi zhurnal [Ukrainian-Romanian relations: history and modernity. A Ukrainian historical journal] № 3. P. 26. [in Ukrainian]; Kozak V. (October 12, 2001) 270 hektariv uzhe vtracheno na kordoni z Rumuniyeyu/ Kozak V. // Dzerkalo tyzhnia. [270 hectares have already been lost on the border with Romania / V. Kozak] - P. 3. [in Ukrainian]; Kravchenko V. (October 12, 2002) Ukrayina ta Rumuniya: pryhovana napruha / Kravchenko V // Ukrayinskyi monitorynh. [Ukraine and Romania: hidden tensions] [in Ukrainian].

7 Rendiuk T. G. [2010] Ukrayintsi Rumuniyi: natsionalno-kulturne zhyttia ta vzayemovidnosyny z vladoyu [Ukrainians in Romania: national and cultural life and relations with the authorities] Kyiv: Instytut istoriyi Ukrayiny NAN Ukrayiny. P. 142-143. [in Ukrainian].

${ }^{8}$ Bruter V. I. (September-October 2000) Ukrainsty Yuzhnoi Bukoviny: problem i perspektivy/Sbornik nauchnykh konferentsyi "Transgranichnoye sotrudnichestvo Ukrainy, Moldovy I Rumynii”. Sait Mezhdunarodnoho instituta gumanitarno-politicheskih issledovaniy. [The Ukrainians of Southern Bukovina: problems and perspectives/A collection of scientific conferenses "Transborder cooperation of Ukraine, Moldavia and Romania". The site of the International Institute for Humanitarian and Political Studies] URL: http://www.igpi.ru/info/people/bruter/1086170286.html. [in Russian]. 
space are being supported by the Constitution of Romania of $2003^{9}$, the European Charter for Regional or Minority Languages (signed but not ratified by Romania), the Framework Convention for the Protection of National Minorities, the Law on local public administration (№ 271/2001), the Regulations on the Elections to the Chamber of Deputies and the Senate of Romania (№68/1992) with its changes and appendices, the Law on education (№ 84/1995) with its changes and appendices, and the Treaty on Relations of Good-Neighborliness and Cooperation between Ukraine and Romania of June 2, $1997^{10}$.

The aim of our research is to analyze the socio-historical background of the functioning of the Ukrainian periodicals of Romania under various political conditions, to determine the main problems of its contemporary development and to outline the possible perspectives of their development.

The Ukrainian language has undergone different changes in the sphere of education, culture and mass media in Romania. The Ukrainians felt the tough policy of assimilation during the interwar period. The fact of "forceful Romanization of the Ukrainian population during the interwar period has been confirmed by the very Romanian scholars. A bright example of this is the "Nations and minorities", the work of Gabriel Andreescu, the editor in chief of the New Journal of Human Rights and the founder of the Ombudspersons for National Minorities organization that was published in Bucharest in 2004. The work contains the following statement relevant to our research: "During the framework of the Romanization campaign, the Romanian government closed or disbanded Ukrainian schools, newspapers and educational facilities at the beginning of the '30s. It was forbidden to use Ukrainian in public life. Violating the law could lead to the intervention of the police. The Ukrainians were called "Romanians that have forgotten their native language" ${ }^{11}$.

The national-cultural situation of the Romanian Ukrainians improved after World War II. Subjects in schools in the villages and towns of high concentration of Ukrainians and mixed families were taught in Ukrainian,

\footnotetext{
${ }^{9}$ Constituţia România (Constitution of Romania) URL: http://www.constitutiaromaniei.ro/. [in Romanian].

${ }_{10}$ Dohovirno-pravova baza mizh Ukrainoyu ta Rumuniyeyu / Ofitsiynyi sait Posolstva Ukrainy v Rumunii [Legal framework between Ukraine and Romania / Official site of the Embassy of Ukraine in Romania] URL: http://romania.mfa.gov.ua/ua/ukraine-ro/legal-act [in Ukrainian].

${ }_{11}$ Popovych M. A. (2000) Ukrayina - Uhorschyna: spivpratsia na rivni ministerstv I rehioniv / Kalendar ukrayintsiv Uhorschyny na 2000 rik. [Ukraine - Hungary: cooperation at the level of ministries and regions / Calendar of Ukrainians in Hungary for 2000] Uzhgorod: Mystetska liniya. P. 30-31. [in Ukrainian].
} 
the educational facilities became venues of Ukrainian life where religious and national holidays, memorable dates of great Ukrainians were held.

The expansion of the Ukrainian information-communication segment in Romania began in 1948 when the Grand National Assembly of Romania approved the new law reforming the public education and introduced the compulsory primary and lower secondary education ( 7 grades) in the native language. Though the new educational system of Romania copied the Soviet model to much extent by its form, in general, it led to a positive result. Ukrainian schools were established in every settlement where Ukrainians lived, even in small towns of their residence. There were 116 Ukrainian-language schools of various degree levels and 4 lyceums (Sighetu Marmației, Tulcea, Suceava and Siret) that prepared teachers for Ukrainian schools in the villages of Romania between $1948-1960^{12}$. At the same time, the Ukrainian department of the philological faculty of the University of Bucharest was established (1952) ${ }^{13}$.

The renewal of the Ukrainian-language communication in Romania of the time resulted in the preservation of the national identity and led to unprecedented improvement of cultural activities: literature was born, books were printed in the native language the author of which were representatives of the young Ukrainian intelligentsia ${ }^{14}$. A big role in the renewal of the national identity of the Ukrainians of Romania in the late ' $40 \mathrm{~s}$ - early ' 50 s of the $20^{\text {th }}$ century was played by the representatives of the elder generation of the Ukrainian intelligentsia who "did not forget their national roots despite the forceful Romanization during the interwar period. Having no opportunities for self-realization at that time, highlyqualified refugees of Ukrainian origin from Southern Bukovina in 1940 and 1944 found themselves in an advantageous situation where they could benefit from their professional potential and knowledge of the Ukrainian language in their society. Owing to them, for instance, it was possible to quickly enough

12 Popovych M. A. (2000) Ukrayina - Uhorschyna: spivpratsia na rivni ministerstv I rehioniv / Kalendar ukrayintsiv Uhorschyny na 2000 rik. [Ukraine - Hungary: cooperation at the level of ministries and regions / Calendar of Ukrainians in Hungary for 2000] Uzhgorod: Mystetska liniya. P. 56-57. [in Ukrainian].

${ }^{13}$ Voloschuk Y. I. (2015) Problematyka periodyky ukrayinskoi natsionalnoi menshyny v Rumunii / Naukovyi chasopys NPU im. M. P. Dragomanova. Ser. 22: Politychni nauky ta metodyka vykladannia suspilnopolitychnykh dystsyplin. [The problem of the periodicals of the Ukrainian national minority of Romania / The scientific periodical of the National Pedagogical Dragomanov University. Ed. 22: Political sciences and the methodology of teaching social sciences]. Kyiv: NPU im M. P. Dragomanova. Ed.: 16. P. 4. [in Ukrainian].

14 Bruter V. I. (September-October 2000) Ukrainsty Yuzhnoi Bukoviny: problem i perspektivy/Sbornik nauchnykh konferentsyi "Transgranichnoye sotrudnichestvo Ukrainy, Moldovy I Rumynii”. Sait Mezhdunarodnoho instituta gumanitarno-politicheskih issledovaniy. [The Ukrainians of Southern Bukovina: problems and perspectives/A collection of scientific conferenses "Transborder cooperation of Ukraine, Moldavia and Romania". The site of the International Institute for Humanitarian and Political Studies] URL: http://www.igpi.ru/info/people/bruter/1086170286.html. [in Russian]. 
arrange teaching not only Ukrainian language and literature but also other subjects in the native language in the newly-established Ukrainian educational facilities; this was an unprecedented example for Romania"15.

Beginning with May 1949, such development of the Ukrainian community led to the possibility of publishing the Vilne slovo biweekly newspaper in Romania. It remained the only Ukrainian periodical for a long time. The newspaper actively published topical material about the life of the community and works of fiction in the native language. The periodical became a platform enabling the writers of Bukovina, newcomers and emigrants from Suceava and Maramureș counties to reveal their creative abilities ${ }^{16}$. The literary production grew so rapidly that the periodical could not encompass everything. The most energetic publishing activity of the Ukrainians of Romania took place in the '40'50s of the previous century. Aside from school books and social-political literature, works of poets like Oksana Melnyk, Ivan Shulyak, Havril Klempush, Yuriy Pavlish and prose writers like Ivan Fedko, Stelyavin Yatsentiuk, Korneliy Rehul etc. are published in the native language. Soon, beginning from 1979, the larger literary requests in Ukrainian of Novyi vik began to be satisfied by the "Literaturnyi dodatok" (editor-in-chief I. Kovach) that became a separate literature and arts journal under the title Nash holos.

The development of the Ukrainian printed word was supported by the Constitution of the Romanian People's Republic (1952). It guaranteed its citizens full and equal rights in all fields of economic, political and cultural life regardless of their nationality and race. According to this Constitution, the Hungarians as the largest national community after the Romanians were given the right to form the Magyar Autonomous Region. The Ukrainian government was hugely providing the Romanian Ukrainians with scientific material, literature, teaching aids and textbooks during the period of the formation of the Ukrainian periodicals. A part of the youth was given the opportunity to study in Ukraine. However, the uncertain heyday of the Ukrainian press in Romania lasted only around 20 years.

The decline of the Ukrainian periodicals in Romania began in the '60s of the $20^{\text {th }}$ century when the newspaper offices and individual journalists were pursued and harshly treated by the government. Following the sudden death of Gheorghe

15 Rendiuk T. G. [2010] Ukrayintsi Rumuniyi: natsionalno-kulturne zhyttia ta vzayemovidnosyny z vladoyu [Ukrainians in Romania: national and cultural life and relations with the authorities] Kyiv: Instytut istoriyi Ukrayiny NAN Ukrayiny. P. 56-60. [in Ukrainian].

${ }^{16}$ Voloschuk Y. I. (2015) Problematyka periodyky ukrayinskoi natsionalnoi menshyny $\mathrm{v}$ Rumunii / Naukovyi chasopys NPU im. M. P. Dragomanova. Ser. 22: Politychni nauky ta metodyka vykladannia suspilnopolitychnykh dystsyplin. [The problem of the periodicals of the Ukrainian national minority of Romania / The scientific periodical of the National Pedagogical Dragomanov University. Ed. 22: Political sciences and the methodology of teaching social sciences]. Kyiv: NPU im M. P. Dragomanova. Ed.: 16. P. 83. [in Ukrainian]. 
Gheorghiu-Dej (1965), Nicolae Ceaușescu came to power. His political rule turned out to be devastating for the national groups of the country. The Romanian Communist media of the time called Nicolae Ceaușescu as the "Genius of the Carpathians", the "Danube of Thought", the "Creator of an Era of Unprecedented Renewal", the "Source of Light", the "Great Revolutionary Helmsman", the "Hero among the Nation's Heroes" ${ }^{17}$. Suffice it to mention that the hymn of Socialist Romania began with the words: "The Party, Ceauşescu, Romania..."

The new Constitution of Romania (1965) proclaimed a unitarian state. Therefore, the Magyar Autonomous Region was liquidated. In his speech dedicated to the $45^{\text {th }}$ anniversary of the formation of the Romanian Communist Party in 1966, Ceaussescu strongly criticized the determination of Romania as a multinational state. Ceauşescu's policy was nothing about internationalism. As a result, all the Ukrainian schools and lyceums were closed, the Ukrainian Greek Catholic church was prohibited during the '60-80s. Pressures during the applications to the universities and government positions led to mass changes of nationality of the Ukrainians. They renounced their language and changed their surnames ${ }^{18}$.

Ceauşescu's power gradually and deliberately harshened the censorship in the mass media, publishing offices, especially when it concerned editions published in non-Romanian languages. At the new leader's insistence, the legislation of the no longer People's, but Socialist Romania became more violent. To prevent the publishing of any information about the country abroad, it was prohibited to publish any material concerning confidential information about the state outside Romania by the Law on State Secrets of 1971. Such prohibition was among numerous provisions of the law that limited the access of any information, since the definition of "state secret" began to encompass even ordinary topics of economy, not to mention the armed forces, jurisdiction and politics ${ }^{19}$. Moreover, total inspection regarded not only printed products but also

${ }^{17}$ Shama O. (24.02.2015) Istoriya zhyzni I smerti "polnovodnoho Dunaya" - rumynskoho diktatora Nikole Chaushesky / Sait zhurnala "Novoye vremia". [Nicolae Ceaușescu. The story of the life and death of the "Danube of Thought" - Romanian dictator Nicola Ceausescu / Website of the Novoye vremia jorunal. URL: http://nv.ua/publications/-istoriya-zhizni-i-smertipolnovodnogo-dunayarumynskogo-diktatora-nikolae-chaushesku--35987.html. [in Russian].

${ }^{18}$ Samsonenko L. (March 23, 1999) Kym vvazhayut sebe ukrayintsi v Rumunii/Uriadovyi kurier [Who do Ukrainians in Romania consider themselves/Uriadovyi kurier]. [in Ukrainian].

${ }_{19}$ Ukrayina v suchasnomy heopolitychnomy prostory: teoretychnyi I prykladnyi aspekty: [kol. Monogr.]./za red. F. Rudycha [Ukraine in the modern geopolitical space: theoretical and applied aspects: [col. monograph] / under the edited by F. Rudych. Kyiv: MAUP. 2002. 488 p. [in Ukrainian]; Deletant D. Romania 1948-1989: A Historical Overview / Cold War International History Project. URL: http://www.php.isn.ethz.ch/collections/coll_romania/ introduction.cfmRomania, \%2019481989:\%20A\%20Historical\%20Overview\%20by\%20Dennis $\% 20$ Deletant. 
spoken communication. The entire information-communication process of the country was under the control of the secret police, the Securitate. There is an opinion that every tenth or, even, fourth Romanian citizen served as staff or nonstaff informer. The secret police spread rumors that every telephone in Romania was equipped with listening devices and that the Securitate was able to control 10 million phone calls simultaneously ${ }^{20}$.

There is no doubt whatsoever about the fact that every Romanian citizen of the time regardless of their social status met a representative of the secret police that knew everything about them at least once in their lifetime. It is obvious that the aim of the Securitate's total penetration into the public and private life of the citizens meant the possibility to check their loyalty anywhere: in schools, universities, printing houses, editorials, theatres, etc. and at any time. The Securitate's staff was rather powerful, since cooperating with it meant significant benefits, including the opportunity to receive good higher education. Under such conditions, the journalism and the arts glorified the Romanian leader. Those who dared to oppose the general party line, were sent to prison or placed under house arrest. Due to the lack of any human rights movement, the opposition of the citizens was reduced to certain manifestations of disobedience: overhearing the programs of the Radio Free Europe and radio Voice of America, the performances of lecturer Doina Cornea at the University of Cluj-Napoca, or Y. Filip, D. Popa and P. Filipescu, the founders of the Non-official labor union Liberty. The latter was soon arrested for spreading fliers with appeals against Ceaușescu. The poet Mircea Dinescu's critical sayings addressing the regime, did not have any particular effect. The secret services quickly isolated these people and deprived them of their freedom of speech. For instance, Doina Cornea was placed under house arrest for her acts against $\mathrm{N}$. Ceaușescu's policy on the consolidation of villages on December 22, 1989.

The situation of the national-ethnic group of Romania of the time in the media and in the journalism, in general, was even more complicated, since nonRomanian citizens were believed to be not loyal. The intercultural communication between the Ukrainian community and their fellows in the ethnic motherland became almost impossible due to the strong control of the intelligence and agency. According to the actual instructions of the time, communication between Romanian citizens and foreigners could only be possible at the presence of witnesses. The closest bureau of the Securitate had also be informed about the content of the communication in written form on the following day. The owners of typewriters were obliged to register themselves at

${ }^{20}$ Müller H. (12.10.2019) Suchnost Securitate / Sait Internet-izdania "Russkiy zhurnal" [The essence of the Securitate / Website of the Internet publication Russkiy zhurnal] URL: http://www.russ.ru/pole/Suschnost-Sekuritate. [in Russian]. 
the department of home affairs. Moreover, the administrators of restaurants had to control that no window of their facility could be covered with curtain. During the entire reign of $\mathrm{N}$. Ceaușescu, especially the last ten years known as the "Satanic decade", nationalism flared up and there was a constant search for "public enemies".

It was completely obvious that full development of Ukrainian periodicals aiming at the preservation of the ethnic identity could not be possible in the Romania of the time. The country under the reign of $\mathrm{N}$. Ceaușescu resorted to the cultivation of the Romanian nationalism and the war with the "inner national enemy", harassment of people of different nationalities. Having proclaimed the idea of accelerated assimilation of non-Romanian groups of the population, the Romanian Communist party aimed at the creation of a "united Romanian socialist nation" that would engulf the Hungarians, Ukrainians, Germans, Bulgarians, and others. Discrimination processes against the Ukrainian population and its national-cultural traditions were strengthened. The Novyi svit ("New world") periodical suffered a tragic fate. In 1960, there were still journalists conscious of the Ukrainian population in the editorships, though, soon enough they were blamed for the so-called nationalism and were sent to jail following their trials" ${ }^{21}$.

Later, there were attempts to divide the Ukrainians of Romania into fictional nationalities: Hutsuls, Rusyns, Khokhols. A chapter personally edited by N. Ceaușescu was included in the Program of the Romanian Communist Party in 1974. It represented the scheme of the historical development of Romania beginning with the ancient times, i. e. the process of the establishment of the great Romanian nation. The entire document is full of historical myths, disregard for other nations and desire to assert the Romanian nationalism.

Not only journalism, publishing and education but also the national-cultural activity of the Ukrainians of Romania were subjected to complete persecution under such conditions. Most of the Ukrainian-language schools had been liquidated (only the Ukrainian department at the gymnasium of Sighetu Marmatiei and the Ukrainian lectureship of the University of Bucharest survived) since the second half of the ' $60 \mathrm{~s}$ of the $20^{\text {th }}$ century. Almost the entire Ukrainian educational-cultural activity was banned: preschool facilities, primary schools, 8-grade and secondary schools had been liquidated, it was forbidden to use the Ukrainian names of the places. The native language was

${ }^{21}$ Voloschuk Y. I. (2015) Problematyka periodyky ukrayinskoi natsionalnoi menshyny v Rumunii / Naukovyi chasopys NPU im. M. P. Dragomanova. Ser. 22: Politychni nauky ta metodyka vykladannia suspilnopolitychnykh dystsyplin. [The problem of the periodicals of the Ukrainian national minority of Romania / The scientific periodical of the National Pedagogical Dragomanov University. Ed. 22: Political sciences and the methodology of teaching social sciences]. Kyiv: NPU im M. P. Dragomanova. Ed.: 16. P. 83. [in Ukrainian]. 
only an option or was taught at the request of the students in 63 schools of places of high concentration of the Ukrainian minority. Ukrainian-language education was conducted only in the Taras Shevchenko lyceum (Sighetu Marmației, Maramureș county) at the time.

Formally, the Romanian Constitution of 1965 declared the right of using the native language and preserving the national identity, in particular, publishing books, newspapers, journals in the native language. Instead, the Romanian government approved several laws restricting the activity of the ethnic mass media of the country in the '70-' 80 s of the $20^{\text {th }}$ century. Thus, the government passed an act to decrease the format and the periodicity of certain central and county magazines in 1974. Therefore, some daily newspapers turned into weekly ones. Soon, the periodicity of the Romanian editions was restored but the magazines of the national minorities were still published on a weekly basis. The central television of Romania stopped transmitting programs in Hungarian, even though the fact that the population of Hungarians is the second largest after that of the Romanians'. In one year (1985), all the radio and television programs in the languages of national minorities were suspended, including the Ukrainian editions of the county radio stations of Iași and Cluj-Napoca.

Significant damage to the Ukrainian-language villages of Romania was caused by the so-called revolutions: the "industrial" (the building of the Danube - Black Sea canal, developments in the field of nuclear energy), the "mini-cultural" the model of which was borrowed from China. Nevertheless, the most harm to the Ukrainian settlements was caused by the revolution in agriculture, since it destroyed entire villages.

N. Ceauşescu announced his intention to organize another "agricultural revolution" in the consolidation (merging) of villages in March 1988. Since agriculture being the main source of replenishment of currency reserves, it preserved a low level of labor productivity. Therefore, the leader of Romania decided to apply one of the reorganization projects of agriculture on the industrial basis that was under discussion in the Soviet Union back in the days of Khrushchev. There was a plan to build "agro-industrial centers" instead of 13000 villages. Someone called this program the "bulldozer reform" and published so in the periodicals of the time. The campaign of the consolidation of the villages provoked protests abroad and among the cultural workers of Romania. Numerous groups of France, Belgium, Switzerland and Great Britain took part in movements to protect the villages of Romania. The statement of the Congress of Local and Regional Authorities was published at the meeting of the Council of Europe in March 1989. It strongly criticized and condemned the campaign of liquidation of 
villages and demanded the Romanian government to put an end to its policy. One of the BBC channels transmitted Charles, Prince of Wale's performance against the deliberate destruction of villages in Romania. In addition, the Prince supported several European funds that condemned the policy of Ceaușescu. Established in 1987, the Mihai Eminescu Trust launched a broad international campaign to draw the attention of the world community to the process of liquidation of villages. Demonstrations connected with these events took place in many European countries (France, Switzerland, the Netherlands, Belgium). They demanded "the preservation of the Romanian villages" $^{\text {22 }}$. The process of "adoption of Romanian villages" by communes of Western European countries began. Great Britain itself "adopted" 52 villages in Romania thanks to the royal family by September 1989.

The end of spoken and written communication in the native language facilitated the Romanization in the regions of high concentration of Ukrainians. "Qualified officials and specialists" of the titular nation were sent to the places of high concentration of Ukrainians, Hungarians, Serbs and Germans. Their task was to implement the Romanian language in the respective national environment. It should be noted in this context that the presence of ethnic Romanians in the environment of the "joint residence of nationalities" significantly eased the Romanization of the latter, especially since the beginning of the ban on using the native languages of the national minorities. This dual process of assimilation of the national minorities, including Ukrainians, covered the region of their high concentration: Transylvania, Banat, Maramureș, Southern Bukovina and Dobruja counties. The ratio of nationalities has changed significantly in favor of Romanians in short time ${ }^{23}$.

The situation of the Ukrainian-language media of Romania somewhat improved after the fall of the totalitarian regime of N. Ceaușescu. However, the analysis of the scientific literature and periodicals confirms that the situation of the culture of the Ukrainian Romanians still remains to be complicated. Moreover, some of the Ukrainian events in Romania resemble a duty that should be done during the visits of Ukrainian high-ranking officials. This often regards the Union of the Ukrainians of Romania (established in 1990) that conducts cultural and artistic events rather often (partly at the expense of the Romanian state budget, financial support from

22 Kravchenko V. (October 12, 2002) Ukrayina ta Rumuniya: pryhovana napruha / Kravchenko V // Ukrayinskyi monitorynh. [Ukraine and Romania: hidden tensions] [in Ukrainian].

${ }_{23}$ Rendiuk T. G. [2010] Ukrayintsi Rumuniyi: natsionalno-kulturne zhyttia ta vzayemovidnosyny z vladoyu [Ukrainians in Romania: national and cultural life and relations with the authorities] Kyiv: Instytut istoriyi Ukrayiny NAN Ukrayiny. P. 71. [in Ukrainian]. 
Ukraine and sponsorship funds). The Struny ne hostyny children's vocalinstrumental collective and the Svekrukhy vocal band are functioning in Suceava county. The local Union in Bucharest operates the Zorya ensemble that participates in national and international festivals. In addition, the Ukrainian cultural house of Timiș county functions in Timișoara.

The Union of the Ukrainians of Romania prints periodicals partly at the expense of the Romanian state budget (3 Ukrainian-language and 1 Romanian-language periodical). In particular, these are the following: Ukrainskyi visnyk (editor in chief - Mykhailo Mykhailiuk) in Bucharest, Vilne slovo cultural and educational magazine of Bucharest (editor in chief Ivan Kovach), the Romanian-language periodical Curierul ucrainean ("Ukrainian herald", editor in chief - Ivan Robchuk), the literary and cultural magazine of the Ukrainian writers of Romania Nash holos (editor in chief Iryna Moisey). An important role in the ethnic education of the Ukrainian youth is played by the journal Dzvonyk (editor in chief - Mykola Korsak).

Nevertheless, the circulation of the above-mentioned periodicals of the Union of the Ukrainians of Romania is not significant. They are published 1-2 times per month and often cannot be delivered to the reader due to the lack of a distribution system. Regional radio stations of three cities (ClujNapoca, Timişoara and Iași) transmit 15-20 minutes of programs in Ukrainian every week that constitute 13-17 hours per year. The second channel of the central television of Romania transmits a 30-minute program Convieţuire ("Cohabitation") in the languages of national minorities twice a month. However, programs dedicated to the Ukrainian population of Romania are usually transmitted thrice per year.

Neither was it easy to turn the old Novyi vik newspaper with its low circulation into a contemporary cultural and educational magazine. Tribute should be paid to editor in chief of the reformed and modernized illustrated innovation with a symbolic title Vilne slovo. It was no one else than Ivan Kovach, poet, prose writer, an active preserver of the Ukrainian community. Praiseworthy is the work of Iryna Petretska-Kovach and Roman Petrashak and formerly Stepan Tkachuk (Vilne slovo, 2014, № 23-24). The representatives of the Ukrainian diplomatic mission have been overseeing the affairs of the Ukrainian community of Romania even in the toughest times. This is confirmed by the profound analysis of the situation and the high estimation of the work of the Ukrainian editorships of Romania in the "Letter from T. Bauer, Extraordinary and Plenipotentiary Ambassador of Ukraine to Romania to the editorship of the cultural and educational magazine of the Union of the Ukrainians of Romania Vilne slovo (2014, № 23-24). The Union of the Ukrainians of Romania (head - Stepan 
Buchuta) considers its main task in the preservation of the national identity of the Ukrainians, the renewal of the Ukrainian culture, native language, own traditions, Ukrainian-language mass media, publicist and literary works of Ukrainian writers of Romania (Ukrainskyi visnyk, 2010, № 3-4 (February). However, this process is very weak and has little influence on the young generation of Ukrainians in this country. Unlike the Ukrainian associations of Slovakia and Hungary that can raise the issue of the national identity of Ukrainians in these countries rather sharply and discuss the ensuring of the national rights thanks to their press and national media, the Ukrainian press and associations of Romania do this very carefully. Surprisingly enough, even the heads of the Ukrainian communities of Romania are afraid of the criticism by the Romanian national policy in regards of the Romanian Ukrainians even on the pages of the periodicals published in Ukraine.

Thus, problems of freedom of conscience and freedom of the press are raised in M. Mykhailiuk's article under the title "Stains on positive discrimination". The author recalls the tough totalitarian times of the Communist regime in Romania when the Romanian press did almost no mentions of the Ukrainians. He notes that the Ukrainian's situation has "significantly improved" since 1989. "We have our own association, publish newspapers and books, hold cultural festivals, make an appearance on radio and television, have our representative at the Parliament, keep in touch with the historical motherland and the Ukrainian diaspora from everywhere, try to renew education in the native language and the native church..." (Ukrainskyi visnyk, 2002. № 9-10). M. Mykhailiuk is outraged by the false information in the press about the Ukrainians being blamed for many problems. However, the author's conclusion is surprising enough. He states that "there would not be such fiction, if the Romanian press wrote about real "positive discrimination" thanks to which the Ukrainians are establishing their national-cultural life while remaining loyal Romanian citizens at the same time." The conclusion of the article leaves an unpleasant feeling. It says that discrimination on the basis of nationality may have a positive aspect.

A publication of Stepan Tkachuk, the head of the Union of the Ukrainians of Romania in this edition of the periodical under the title "Denationalization of the Ukrainian settlements of Romania" is somewhat critical. However, the author addresses only one aspect of this problem. It is the humiliating attitude towards the situation of the Ukrainian Orthodox church in Romania. S. Tkachuk is completely right to say that religion and spirituality make up the basis of the national renewal. "Ukrainians as any other nation want to pray to God in their native language. They want that 
Liturgies were conducted in Ukrainian" (2002, № 9-10). Though, the statement that "the arrogance and chauvinism of the Romanian church hierarchs" that still "create an image of godlessness and degenerate" the Ukrainians in the name of God should be ended once and for all is not tolerant and considered ironically.

The assimilation and denationalization processes in Romania are clearly exemplified by the information of M. Machoka. This issue is represented in the Ukrainskyi visnyk (2001, № 15-16.) periodical: the Ukrainian population of Satu Mare county officially constituted 1362 people, though, in fact, it was a lot more. Out of 301105 Ukrainians, 3439 lived in this county in 1930. The population of the county made up 400789 out of which the Ukrainians made up only $0.3 \%$ in 1992 . The number of Ukrainians fell by 2037 people by this time. This could not be the result of natural cause, since the birth rate of the Ukrainian community is rather high. To M. Machoka's mind, Ukrainians did not disappear but became the victims of the assimilation processes. 630 Ukrainians lived in the village of Halmeu that is located near the Ukrainian border in 1930. By 1992, there remained only 5 Ukrainians. The village of Lazuri counted as many as 730 Ukrainians in 1930. By the time of 1992, there remained only 10 of them. The assimilation process is even stronger confirmed by the fact that the census of some typically Ukrainian villages did not mention any Ukrainians in 1992. The falsification was clarified "during a survey of the Ukrainian population of Romania in 1998. It was conducted with the residents and representatives of the authority of Ipotești and Semenychi villages of Botoșani county". They found out that there were no facilities that would satisfy the national-cultural needs of the Ukrainians in the Ukrainian villages. Though, "391 residents of Semenychi would like that their children knew the Ukrainian language" 24.

The Ukrainian press in Romania actively raises the problem of the Ukrainian identity in the modern time. This topic is often represented in the light of the Ukrainian spirituality and religion, in particular, in such materials of the Ukrainskyi visnyk as: "The Holy Sacrament of the Priesthood", "The Holy Sacrament of Anointing" (2002, № 9-10), "Christ is Born. Praise Him", "For the Unity of the Church "(2002. № 17-18), "Christmas Greetings of the World Congress of Ukrainians", "Voice of the Church of the Holy Christmas" (2003. № 1-2), "Easter", "Christ is Risen", "Sin before God's Judgment" (2003, № 5-6), "God's Mercy", "Native

${ }^{24}$ Aza L. O. (1999) Ukraintsi Rumunii: suchasnyi stan ta perspektivy etnokulturnoho rozvytku [The Ukrainians of Romania: the modern state and the perspectives of the ethnocultural development] Kyiv: Sotsis, Rivne: Lista. P. 17-45. [in Ukrainian]. 
Churches" (2003, № 13-14), "The Earthly Life of Jesus and His Significance for Us, Christians" (2003, № 15-16).

Noteworthy is the problem of studying the native language that is actively discussed on the pages of the mentioned periodical. For instance, by drawing conclusions of the student competition in the Ukrainian language in his material under the title "Holiday of the native language" (2003, № 9-10), M. Korsiuk reports on the event and occasionally draws the readers' attention to how to improve the methodology of teaching the native language to students. The author rightly notes that instilling the love to the mother tongue is the task not only of the philologists but also of every pedagogue that should facilitate the education of young people in the spirit of patriotism, pride for their nation. At the same time, M. Korsiuk proposes to organize meetings of teachers of the Ukrainian language in order to share knowledge, "to think about the ways of improvement of the level of teaching, to discuss the difficulties we have to face in teaching as a group." In addition, the author analyzes the students' level of education in the regions of high concentration of Ukrainians and points out the possibilities of improvement.

The harm of using too many words of foreign origin is discussed in S. Tkachuk's article under the title "Let us not litter our "nightingale" language". In it, the author urges the readers "not to harm the native language with ignorance..., of course, each language borrows the words it needs from foreign languages. Though, they acquire words that express something beautiful and not some rubbish" (2003, № 13-14). Almost every edition of the Ukrainskyi visnyk and the Vilne slovo publish materials about the culture and the national life of the Ukrainian community of Romania: "The Festival of the Ukrainian carols and winter rites in Banat county" Ukrainskyi visnyk, 2003, № 1-2), "From the Chronicle of the Recent Ukrainian Cultural Events" (Ukrainskyi visnyk, 2003, № 15-16), "How Many Ukrainians are there in Romania and where do they live?" (Ukrainskyi visnyk, 2003, № 15-16), "Pysanka is a masterpiece of the Ukrainian nation", "A Ukrainian song sounded again in Caraș-Severin county" (Vilne slovo, May 2012) etc.

However, the inner situation of the Ukrainian community of Romania does not facilitate the active improvement of the native-language press, since there have been disputes and quarrels for a long time. There was a split in the Ukrainian elite of Romania in the middle of the ' 90 s of the $20^{\text {th }}$ century. It resulted in the foundation of the Democratic Union of Ukrainians of Romania (DUUR was established in 1995, head - Dmytro Morgan) as an oppositional public organization against the Union of the Ukrainians of 
Romania. The main task of the DUUR was to resist the leadership of the UUR due to the fact of spreading compromising information in the Ukrainian and Romanian printed media. The Democratic Union of Ukrainians of Romania was publishing a cultural journal of the Ukrainians of Romania and the diaspora under the title Verkhovyna (in Romanian) and a bilingual Ukrainian-Romanian journal Nasha dumka ("Our opinion") with sponsorship.

The DUUR has in fact ceased its existence in the beginning of 2009. The National Forum of Ukrainians of Romania was established in June 2009 as an organization of the ethnic Ukrainians of Romania. It began its functioning in Suceava county but expanded to the territory of other counties of high concentration of Ukrainians. The head of this organization is Oleksandr Mandiuk and he is a member of the Social Democratic Party of Romania. The back bone of the NFUR became the former members of the DUUR. It should be noted that according to political scientists, the NFUR maintains friendly relations with the Vicariate of the Ukrainian Greek Catholic Church and the Union of the Hutsuls (this organization is not recorded officially).

In general, the analysis of the Ukrainian-language periodicals of Romania confirms the complexity of the national-cultural situation in this country from the point of view of preservation of the ethnic identity of the Ukrainian community. Despite the fact that separate issues of this problem are raised in the Ukrainian periodicals, we agree with A. Sheichuk's and T. Rendiuk's opinion. According to it, the periodicity and the form of presenting the materials of the Ukrainian-language editions of Romania do not always meet the reader's demand ${ }^{25}$ and their content has been marked by "a constant expression of praise and thanks to the Romanian government and throwing mud at the opponents for a long time". Can anybody show at least one single critical article that would be printed in these "salon" publications..., that would objectively express the catastrophic situation of the spiritual condition of the Ukrainians of Southern Bukovina"26.

However, the deep political issues in the Ukrainian-language publications in Romania are exceptions rather than the rule. Most of the materials in these magazines are devoted to the problems of preserving the language, culture, history of the native people, the spiritual revival of the

${ }^{25}$ Sheichuk A. (2006) Ukrayintsi Pivdennoi Bukovini: "quo vadis?" / Nasha dumka [Ukrainians of Southern Bukovina: "quo vadis?” / Nasha dumka]. № 1(2). P. 4. [in Ukrainian]; Rendiuk T. G. [2010] Ukrayintsi Rumuniyi: natsionalno-kulturne zhyttia ta vzayemovidnosyny $\mathrm{z}$ vladoyu [Ukrainians in Romania: national and cultural life and relations with the authorities] Kyiv: Instytut istoriyi Ukrayiny NAN Ukrayiny. P. 100. [in Ukrainian].

${ }^{26}$ Sheichuk A. (2006) Ukrayintsi Pivdennoi Bukovini: "quo vadis?" / Nasha dumka [Ukrainians of Southern Bukovina: "quo vadis?" / Nasha dumka]. № 1(2). P. 4. [in Ukrainian] 
Ukrainian ethnic group. It is of pleasant exception that there are some separate publications that have appeared in this context recently. No doubt that this issue is much deeper, since according to researchers, "many Romanians... are not ready to share their national state with other national groups" ${ }^{27}$. Not only the Ukrainian press of Romania is characterized by weak defense of the interests of the Ukrainians, the lack of topical materials, unwillingness to actively influence politics in the state. The activity of the leaders of the Ukrainian national associations is also balanced and careful. Unlike the Ukrainian ethnos, the Hungarians and Gypsies achieved representation in the transitional parliament from the temporary council of national unity immediately after the revolution of 1989 when mass protests took place under the slogan "No to chauvinism". It is also true that such activities led to clashes between Romanians, on the one hand, and Hungarians and Gypsies, on the other in Târgu Mureș on March 19 and 20, 1990 "As a result, 400 people injured and 5 were killed. There have been significant changes in the atmosphere of relations throughout the country" ${ }^{28}$. As a result, extremist Romanian national movements and parties appeared in Romania. Among the most influencive are Partidul Uniunii Naţionale al României (Party of the National Union of Romania) and Partidul România Mare (Greater Romania Party). The formation of nationalistically oriented parties, correspondingly, led to interethnic tensions and even moderate Romanian parties armed themselves with some of these nationalist slogans.

It is enshrined in the Romanian law that as a national minority the Ukrainians have one reserved seat at the parliament. It is occupied by S. Buchuta, the head of the UUR. The Union is also represented in the Council of National Minorities, the advisory body to the Romanian Government that unites all the officially acknowledged public organizations of the national minorities. A consulate of the Union of the Ukrainians of Romania must function in every county with high concentration of Ukrainians (there are nine such counties). In addition, funds (almost one million euro) are allocated from the Romanian state budget for the activities of the UUR annually. However, while making claims about the situation of the Romanian community in our state to Ukraine, Romania often does not comply with its obligations in regards to supporting the ethnic communities. Thus, the Romanian government planned to completely restore the

27 Rendiuk T. G. [2010] Ukrayintsi Rumuniyi: natsionalno-kulturne zhyttia ta vzayemovidnosyny z vladoyu [Ukrainians in Romania: national and cultural life and relations with the authorities] Kyiv: Instytut istoriyi Ukrayiny NAN Ukrayiny. P. 417. [in Ukrainian].

${ }_{28}$ Rendiuk T. G. [2010] Ukrayintsi Rumuniyi: natsionalno-kulturne zhyttia ta vzayemovidnosyny z vladoyu [Ukrainians in Romania: national and cultural life and relations with the authorities] Kyiv: Instytut istoriyi Ukrayiny NAN Ukrayiny. P. 417. [in Ukrainian]. 
Ukrainian lyceum on the basis of the Lațcu Vodă lyceum (Siret, Suceava county) by 2011 . However, in 2013 , there were only four classes in the lyceum in which the Ukrainian language was taught as a separate subject. Regarding the current state of higher education, only three Romanian universities (the University of Bucharest, Stefan cel Mare University of Suceava county, Babeş-Bolyai University of Cluj-Napoca) offer courses of Ukrainian language and literature at their philological faculty and communication sciences by the department of Slavic (Romanian) languages and literature. From 10 to 15 students study at these departments every year.

\section{CONCLUSIONS}

The entire complex of the social-political, information-communication and other problems causes weakness and overcautiousness of the already weak Ukrainian national movement of Romania. This is also the reason for the specific, mostly cultural, topics and issues of the Ukrainian-language magazines. After the fall of N. Ceaușescu's regime, the Ukrainian scientific circles have not drawn enough attention to this problem yet. Romania being one of the largest neighbors of Ukraine plays an important geopolitical role in Central Europe and in the Balkans at the same time. Authoritative political scientists define several extremely significant factors of the Romanian vector.

However, this could be the topic of a separate scientific research. As we mentioned before, the social-political and economic changes that took place in Romania in 1990 opened a new stage in the development of the Romanian community. In accordance with article 30 of the Constitution of Romania, all citizens of the state including alien ethnic groups that reside on the territory of the state are guaranteed the right to freedom of speech, expression of will (via printed and audio-visual mass media) and the free development of the national culture etc. Any type of censorship is forbidden and no printed issue can be closed ${ }^{29}$.

All the processes that took place in Romania at the end of the $20^{\text {th }}-$ the beginning of the $21^{\text {st }}$ century activated the Ukrainian national movement and

\footnotetext{
${ }^{29}$ Constituţia România (Constitution of Romania) URL: http://www.constitutiaromaniei.ro/. [in Romanian]; Melnychuk I. Problema pasportyzatsii Rumuniyeyu ukrayinskoho naselennia: suchasni realii ta mozhlyvi naslidky rozvytku podiy / Internet-vydannia "Zakarpattia-onlain" [The problem of Romanian certification of the Ukrainian population: modern realities and possible consequences of events / Online publication Zakarpattia-onlain. URL: http://zakarpattya.net.ua/ukr-news-70469-Problema-pasportyzatsiiRumuniieiu-ukrainskohonaselennia:-suchasni-realii-ta-mozhlyvi-naslidkyrozvytku-podii/ [in Ukrainian]; Ukrayina $\mathrm{v}$ suchasnomy heopolitychnomy prostory: teoretychnyi I prykladnyi aspekty: [kol. Monogr.]./za red. F. Rudycha [Ukraine in the modern geopolitical space: theoretical and applied aspects: [col. monograph] / under the edited by F. Rudych. Kyiv: MAUP. 2002. P. 410-424. [in Ukrainian].
} 
facilitate the improvement of the national self-identity of the ethnic Ukrainians to some extent. Thus, in general, the democratic processes that occurred in Romania at the turn of the $21^{\text {st }}$ century, stimulate the development of the press of the national minorities and contribute to the preservation of the national self-identity of the Ukrainian ethnos. At the same time, we should note that, if the conditions of information support in the native language of the Ukrainians of Hungary have been rapidly improving in the recent years (from non-recognizing the existence of the Ukrainian ethnic group on the territory of Hungary to supporting it by the state), then the situation is different in Romania. The active years of the Romanization of the Ukrainian-speaking citizens, closing down Ukrainian schools that was often qualified as a natural process, distributing Ukrainianlanguage topics to Ukrainians in the Romanian language (Curierul ucrainean) led to the rapid decrease of the population of the Ukrainian ethnos.

The Ukrainian-language press of Romania is too weak. It appears not periodically. It lacks a well-established subscription and distribution system, the level of state support for Ukrainian media by both countries is insufficient. Though, the rights of the Ukrainians as a national minority of Romania to information language are declared by laws, preconditions appear that make the Ukrainians forget their native language in the state. For instance, a masked process of assimilation of the Ukrainian population is taking place in the Romanian-language environment. Despite the formation of the joint Romanian-Ukrainian commission that should monitor this issue, the efforts of the Ukrainian diplomats have not managed to improve the situation yet.

\section{SUMMARY}

Taking into consideration the historical-political and social conditions, the author of the paper gives complex analysis of the peculiarities of the ethnocultural communication of the Ukrainians of Romania, the establishment and development of the Ukrainian-language press in this country, examines the main problems of the modern functions of the Ukrainian printed mass media and outlines the possible perspectives of their development.

\section{REFERENCES}

1. Appatov S. (1998) Ukrainsko-rumunski vidnosyny: istoriya ta suchasnist. Ukrainskyi istorychnyi zhurnal [Ukrainian-Romanian relations: 
history and modernity. A Ukrainian historical journal] № 3. P. 26. [in Ukrainian].

2. Aza L. O. (1999) Ukraintsi Rumunii: suchasnyi stan ta perspektivy etnokulturnoho rozvytku [The Ukrainians of Romania: the modern state and the perspectives of the ethnocultural development] Kyiv: Sotsis, Rivne: Lista. 88 p. [in Ukrainian].

3. Bidzilya Y. M. (2005) Osoblyvosti rozvytku ukrainomovnoi presy v Uhorschyni ta Rumunii / Suchasni problem movoznavstva ta literaturoznavstva. [The peculiarities of the development of the Ukrainianlanguage press in Hungary and Romania / The modern problems of the linguistics and literary studies]. Uzhgorod: Gozprozrah, red.-vydav. Viddil uprav. U spravah presy ta inform. Ed. 9, p. 384-389. [in Ukrainian].

4. Bruter V. I. (September-October 2000) Ukrainsty Yuzhnoi Bukoviny: problem i perspektivy/Sbornik nauchnykh konferentsyi "Transgranichnoye sotrudnichestvo Ukrainy, Moldovy I Rumynii”. Sait Mezhdunarodnoho instituta gumanitarno-politicheskih issledovaniy. [The Ukrainians of Southern Bukovina: problems and perspectives/A collection of scientific conferenses "Transborder cooperation of Ukraine, Moldavia and Romania". The site of the International Institute for Humanitarian and Political Studies] URL: http://www.igpi.ru/info/people/bruter/1086170286.html. [in Russian].

5. Constituţia România (Constitution of Romania) URL: http://www.constitutiaromaniei.ro/. [in Romanian].

6. Deletant D. Romania 1948-1989: A Historical Overview / Cold War International History Project. URL: http://www.php.isn.ethz.ch/collections/ coll_romania/introduction.cfmRomania,\%2019481989:\%20A\%20Historical $\% 20$ Overview\%20by\%20Dennis\%20Deletant.

7. Dohovirno-pravova baza mizh Ukrainoyu ta Rumuniyeyu / Ofitsiynyi sait Posolstva Ukrainy v Rumunii [Legal framework between Ukraine and Romania / Official site of the Embassy of Ukraine in Romania] URL: http://romania.mfa.gov.ua/ua/ukraine-ro/legal-act [in Ukrainian].

8. Kozak V. (October 12, 2001) 270 hektariv uzhe vtracheno na kordoni z Rumuniyeyu/ Kozak V. // Dzerkalo tyzhnia. [270 hectares have already been lost on the border with Romania / V. Kozak] - P. 3. [in Ukrainian].

9. Kravchenko V. (October 12, 2002) Ukrayina ta Rumuniya: pryhovana napruha / Kravchenko V // Ukrayinskyi monitorynh. [Ukraine and Romania: hidden tensions] [in Ukrainian].

10. Melnychuk I. Problema pasportyzatsii Rumuniyeyu ukrayinskoho naselennia: suchasni realii ta mozhlyvi naslidky rozvytku podiy / Internetvydannia "Zakarpattia-onlain" [The problem of Romanian certification of the Ukrainian population: modern realities and possible consequences of 
events / Online publication Zakarpattia-onlain. URL: http://zakarpattya.net.ua/ukr-news-70469-Problema-

pasportyzatsiiRumuniieiu-ukrainskoho-naselennia:-suchasni-realii-tamozhlyvi-naslidkyrozvytku-podii/ [in Ukrainian].

11. Müller H. (12.10.2019) Suchnost Securitate / Sait Internet-izdania "Russkiy zhurnal" [The essence of the Securitate / Website of the Internet publication Russkiy zhurnal] URL: http://www.russ.ru/pole/SuschnostSekuritate. [in Russian].

12. Popovych M. A. (2000) Ukrayina - Uhorschyna: spivpratsia na rivni ministerstv I rehioniv / Kalendar ukrayintsiv Uhorschyny na 2000 rik. [Ukraine - Hungary: cooperation at the level of ministries and regions / Calendar of Ukrainians in Hungary for 2000] Uzhgorod: Mystetska liniya. P. 76-77. [in Ukrainian].

13. Reguş C. Şcola ucraineană învătatorii, cărtile (Ukrainian school, teachers, books) / Curierul ucrainean. 1995. № 14-15. P. 4-5.

14. Rendiuk T. G. [2010] Ukrayintsi Rumuniyi: natsionalno-kulturne zhyttia ta vzayemovidnosyny z vladoyu [Ukrainians in Romania: national and cultural life and relations with the authorities] Kyiv: Instytut istoriyi Ukrayiny NAN Ukrayiny. 150 p. [in Ukrainian].

15. Samsonenko L. (March 23, 1999) Kym vvazhayut sebe ukrayintsi v Rumunii/Uriadovyi kurier [Who do Ukrainians in Romania consider themselves/Uriadovyi kurier]. [in Ukrainian].

16. Shama O. (24.02.2015) Istoriya zhyzni I smerti "polnovodnoho Dunaya" - rumynskoho diktatora Nikole Chaushesky / Sait zhurnala "Novoye vremia". [Nicolae Ceaușescu. The story of the life and death of the "Danube of Thought" - Romanian dictator Nicola Ceausescu / Website of the Novoye vremia jorunal. URL: http://nv.ua/publications/-istoriya-zhiznii-smerti-polnovodnogo-dunayarumynskogo-diktatora-nikolae-chaushesku-35987.html. [in Russian].

17. Sheichuk A. (2006) Ukrayintsi Pivdennoi Bukovini: "quo vadis?" / Nasha dumka [Ukrainians of Southern Bukovina: "quo vadis?" / Nasha dumka]. № 1(2). P. 3-5. [in Ukrainian].

18. Ukrayina v suchasnomy heopolitychnomy prostory: teoretychnyi I prykladnyi aspekty: [kol. Monogr.]./za red. F. Rudycha [Ukraine in the modern geopolitical space: theoretical and applied aspects: [col. monograph] / under the edited by F. Rudych. Kyiv: MAUP. 2002. 488 p. [in Ukrainian].

19. Ukrayinomovna diaspora v Rumuniyi [Elektronnyi resurs] // Internet-sait "Bukovina tolerantna". - Rezhym dostupu [The Ukrainianspeaking diaspora of Romania [Electronic source] // Bukovina tolerantna 
Internet-page. Access: http://buktolerance.com.ua/?page_id=8. - Date of access: 11.08. 2020. [in Ukrainian].

20. Voloschuk Y. I. (2015) Problematyka periodyky ukrayinskoi natsionalnoi menshyny $\mathrm{v}$ Rumunii / Naukovyi chasopys NPU im. M. P. Dragomanova. Ser. 22: Politychni nauky ta metodyka vykladannia suspilnopolitychnykh dystsyplin. [The problem of the periodicals of the Ukrainian national minority of Romania / The scientific periodical of the National Pedagogical Dragomanov University. Ed. 22: Political sciences and the methodology of teaching social sciences]. Kyiv: NPU im M. P. Dragomanova. Ed.: 16. P. 82-86. [in Ukrainian].

\section{Information about the author: Yuriy Bidzilya,} Doctor of Science in Social Communications, Professor, Head of the Department of Journalism, Uzhhorod National University 14, Universytetska str., Uzhgorod, 88000, Ukraine ORCID ID: orcid.org/0000-0001-5134-3239 